\title{
PENGARUH PENGUNGKAPAN HUMAN RESOURCES ACCOUNTING DAN TAX PLANNING TERHADAP NILAI PERUSAHAAN DENGAN KUALITAS AUDIT SEBAGAI VARIABEL MODERATING
}

\author{
Mulyadi $^{1}$, Sihar Tambun ${ }^{2}$ \\ Program Studi Akuntansi, Fakultas Ekonomi Universitas Bhayangkara Jakarta Raya ${ }^{1}$ \\ Fakultas Ekonomi Bisnis, Universitas 17 Agustus 1945 Jakarta $^{2}$ \\ mulyadi_1428@yahoo.com ${ }^{1}$, sihar.tambun@yahoo.com ${ }^{2}$
}

\begin{abstract}
Abstrak
Penelitian ini bertujuan untuk menguji pengaruh pengungkapan HRA dan tax planning terhadap nilai perusahaan dengan kualitas audit sebagai variabel moderating. Penelitian ini memproksikan nilai perusahaan dengan Price Earning Ratio (PER), tax planning diproksikan dengan Effective Tax Rate (ETR), pengungkapan Human Resources Accounting (HRA) diproksikan dengan indeks pengungkapan HRA, dan kualitas audit diproksikan dengan jumlah auditor. Penelitian ini menggunakan data sekunder yang menggunakan pengumpulan data dokumentasi dan studi pustaka pada situs Bursa Efek Indonesia (www.idx.co.id) berupa laporan keuangan tahunan. Populasi yang digunakan dalam penelitian ini adalah perusahaan manufaktur yang terdaftar di Bursa Efek Indonesia periode tahun 2014-2018 dengan teknik pengambilan sampel menggunakan purposive sampling method. Hasil Penelitian ini adalah pengungkapan human resources accounnting (HRA), tax planning dan kualitas audit berpengaruh signifikan terhadap nilai perusahaan, moderasi kualitas audit tidak mampu memperkuat pengaruh pangungkapan HRA terhadap nilai perusahaan. Moderasi kualitas audit mampu memperkuat pengaruh tax planning terhadap nilai perusahaan.
\end{abstract}

Kata Kunci : Pengungkapan HRA, Tax Planning, Nilai Perusahaan, Kualitas Audit.

\begin{abstract}
This research analyzes the influence of HRA disclosure and tax planning on company value with audit quality as a moderating variable.This research proxies the firm value with Price Earning Ratio (PER), tax planning is proxied by Effective Tax Rate (ETR), disclosure of Human Resources Accounting (HRA) is proxied by the HRA disclosure index, Audit quality is proxied by number of auditors. This study uses secondary data that uses documentation and literature study data collection on the Indonesia Stock Exchange's website (www.idx.co.id) is an annual financial report. The population used in this study is manufacturing companies listed on the Indonesia Stock Exchange in the period 2014-2018 with a sampling technique using a purposive sampling method. The result of this research is the disclosure of Human Resources Accounting (HRA), tax planning and quality of audit of significant impact on the firm value, the audit quality moderation is not able to strengthen the influence of HRA's expression of the firm value. Moderation of audit quality is able to strengthen the impact of tax planning on the firm value.
\end{abstract}

Keywords: HRA Disclosure, Tax Planning, Firm Value, Audit Quality.

\section{PENDAHULUAN}

Nilai perusahaan dalam laporan keuangan dapat dilihat dengan nilai sahamnya. Harga saham yang tinggi membuat nilai perusahaan juga tinggi (Tjandrakirana \& Monika, 2014). Price Earning Ratio (PER) adalah salah satu rasio yang digunakan untuk menggambarkan nilai perusahaan. PER dapat digunakan untuk mengukur seberapa besar perbandingan antara harga saham perusahaan dengan keuntungan yang diperoleh para pemegang saham. Naik turunnya harga saham di Pasar Modal berkaitan dengan naik tutunnya nilai perusahaan itu sendiri. Sektor usaha manufaktur memiliki masa depan yang sangat kuat di Indonesia, karena perkembanganya dapat memberikan kontribusi 
terbesar terhadap Produk Domestik Bruto (PDB) Indonesia (Mahpudin \& Suparno, 2016). Berikut ini fenomena harga saham di pasar modal yang ditunjukan oleh tren pergerakan IHSG di Bursa Efek Indonesia dan perkembangan PDB di Indonesia.

Tabel 1.1

Indeks Harga Saham Gabungan 2013-2018

\begin{tabular}{|c|c|c|}
\hline TAHUN & IHSG & DELTA \\
\hline 2018 & 6194.50 & $-2.53 \%$ \\
\hline 2017 & 6355.65 & $19.99 \%$ \\
\hline 2016 & 5296.71 & $15.31 \%$ \\
\hline 2015 & 4593.08 & $-12.12 \%$ \\
\hline 2014 & 5226.47 & $22.28 \%$ \\
\hline 2013 & 4274.17 & \\
\hline
\end{tabular}

Sumber: Bursa Efek Indonesia Tahun 2013-2018

Tabel 1.2

Produk Domestik Bruto Indonesia Tahun 20132018

\begin{tabular}{|c|c|c|}
\hline TAHUN & PDB & DELTA \\
\hline 2018 & $\operatorname{Rp~14837.40~}$ & $9.19 \%$ \\
\hline 2017 & $\operatorname{Rp~} 13588.80$ & $9.53 \%$ \\
\hline 2016 & $\operatorname{Rp~12406.40}$ & $7.59 \%$ \\
\hline 2015 & $\operatorname{Rp~} 11531.70$ & $9.10 \%$ \\
\hline 2014 & $\operatorname{Rp~10569.70}$ & $10.72 \%$ \\
\hline 2013 & $\operatorname{Rp~9546.10}$ & \\
\hline
\end{tabular}

Sumber : Badan Pusat Statistik 2013-2018

Jika IHSG memiliki perubahan naik turun, nilai PDB perubahannya selalu meningkat dari tahun ketahun. Hal itu menginformasikan bahwa secara umum suatu perusahaan selalu mengalami pertumbuhan penjualan dan laba yang mana dapat membuat harga saham atau nilai perusahaan tumbuh setiap tahunnya. Harga saham di pasar modal tidak dapat diprediksi, selalu mengalami kenaikan dan penurunan. Pada tahun 2015 dan 2018 terjadi penurunan harga saham dari tahun sebelumnya tetapi nilai PDB tahun tersebut sangat berbeda, hal ini menunjukan bahwa ternyata tidak semua perusahaan selalu mengalami peningkatan laba. Kedua fenomena ini menggambarkan bahwa nilai perusahaan secara umum cenderung meningkat di Indonesia. Nilai perusahaan tidak terlepas dari kontribusi sumber daya manusianya. Sumberdaya manusia harus dihitung secara cermat, termasuk biaya biaya pengembangan sumber daya manusia. Akuntansi juga harus menghitung serapan biaya sumber daya manusia untuk kemudian dianalis dampaknya terhadap nilai perusahaan. Pengembangan Akuntansi Sumber Daya Manusia (Human Resources Accounting) diperlukan untuk menyediakan laporan perusahaan yang akurat sebagai acuan atau pengambilan keputusan (Widodo, 2014). Penelitian Flamholtz et al. (2002) menyatakan bahwa HRA (Human Resources Accounting) sangat relevan terhadap pengambil keputusan bagi para investor.

Selain pentingnya biaya pengembangan sumber daya manusia untuk membangun nilai perusahaan, perencanaan pajak juga dapat menunjang terciptanya nilai perusahaan. Banyak perusahaan melakukan perencanaan pajak untuk meminimalisir beban pajak yang harus dibayarkan kepada negara, sehingga dengan begitu perusahaan dapat memaksimalkan laba setelah pajak yang akhirnya akan berpengaruh terhadap nilai perusahaan. Penelitian Noviari (2017) menyatakan bahwa variabel perencanaan pajak berpengaruh terhadap nilai perusahaan, penelitian ini didukung oleh penelitian Lestari (2016) yang menyatakan adanya hubungan positif antara perencanaan pajak dan nilai perusahaan. Perusahaan yang mampu melakukan aktivitas perencanaan pajak dengan baik maka perusahaan tersebut mampu meningkatkan nilai perusahaan. Namun terdapat perbedaan dari hasil penelitian Sihotang \& Sitorus (2018) yang menyatakan bahwa tax planning tidak berpengaruh terhadap nilai perusahaan (firm value).

Kemudian mutu audit atas laporan keuangan juga berpotensi mendukung peningkatan nilai perushaaan. Untuk memastikan laporan keuangan yang disusun oleh manajemen sesuai dengan standar yang berlaku maka laporan keuangan harus diaudit oleh auditor yang independen. Semakin tinggi tingkat kompetensi dan independensi auditor akan meningkatkan kredibilitas dari laporan keuangan, dengan meningkatnya kredibilitas dari laporan keuangan maka diharapkan akan berpengaruh terhadap harga saham perusahaan, dan meningkatkan nilai perusahaan (Bachtiar \& Laksito, 2016). Hasil penelitian Juliardi (2013) menyebutkan kualitas audit tidak berpengaruh signifikan terhadap nilai perusahaan, penelitian ini didukung oleh penelitian Nugrahani (2014) yang menyatakan bahwa variabel kualitas audit tidak memiliki pengaruh signifikan terhadap manajemen laba secara individual. Sedangkan pengaruh manajemen laba terhadap nilai perusahaan diterima karena terbukti variabel discretionnary accruals berpengaruh positif signifikan terhadap nilai perusahaan.

Perbedaan penelitian ini dengan penelitipeneliti sebelumnya adalah adanya kualitas audit sebagai variabel moderating, yang diharapkan dapat diketahui dampaknya terhadap pengaruh variabel independent yakni pengungkapan human 
resources accounting dan tax planning terhadap variabel dependent yakni nilai perusahaan. Penelitian ini memfokuskan pada "Pengaruh Pengungkapan Human Resources Accounting (HRA) dan Tax Planning terhadap Nilai Perusahaan dengan Kualitas Audit sebagai Variabel Moderating (Studi Empiris Perusahaan Manufaktur yang terdaftar di BEI Tahun 2014 - 2018)".

Dari latar belakang diatas maka rumusan masalah dalam penelitian ini antara lain pertama, apakah pengungkapan human resources accounting berpengaruh terhadap nilai perusahaan? kedua, apakah tax planning berpengaruh terhadap nilai perusahaan? ketiga, apakah kualitas audit berpengaruh terhadap nilai perusahaan? keempat, apakah kualitas audit mampu memoderasi atas pengaruh pengungkapan HRA terhadap nilai perusahaan? kelima, apakah kualitas audit mampu memoderasi atas pengaruh tax planning terhdap niali perusahaan?.

\section{TINJAUAN PUSTAKA}

\section{Teori Keagenan (Agency Theory)}

1. Grand Theory yang mendasari dalam penelitian ini adalah teori keagenan. Teori keagenan merupakan teori yang menjelaskan hubungan antara agent (manajemen) dan principal (pemilik).

2. Teori keagenan pertama kali dicetuskan oleh Jensen \& Meckling (1976) bahwa teori keagenan ialah perjanjian antara satu atau lebih pihak yang disebut prinsipal dengan pihak lain yaitu agen yang diberi tugas untuk bertindak mengutamakan kepentingan prinsipal dan melibatkan pendelegasian beberapa wewenang dalam pengambilan keputusan. Jika kedua pihak memiliki kepentingan yang tidak sejalan, maka dapat dikatakan agen tidak selalu bertindak sesuai atas dasar kepentingan prinsipal.

3. Jika dikaitkan dengan penelitian ini, teori agensi mempunyai peran sebagai dasar praktik bisnis yang dilakukan untuk meningkatkan nilai perusahaan dan memberikan kemakmuran kepada prinsipal.

4. Nugraheni (2018) menyebutkan bahwa besarnya biaya dan manfaat pengungkapan informasi tertentu berbeda antara perusahaan yang satu dengan perusahaan yang lainnya. Pengungkapan HRA dapat mengurangi masalah keagenan ketika pemegang saham pengendali memiliki insentif manfaat swasta yang lebih tinggi.
Aktivitas perencanaan pajak merupakan suatu tindakan terstruktur agar beban pajak menjadi serendah mungkin dengan memanfaatkan peraturan yang ada untuk memperoleh peningkatan laba setelah pajak yang akan berdampak pada peningkatan nilai perusahaan, dengan mengabaikan tingkat compliance perusahaan.

5. Berdasarkan prespektif agency theory, aktivitas perencanaan pajak dapat memfasilitasi kesempatan manajerial untuk melakukan tindakan oportunisme dengan memanipulasi laba atau penempatan sumber daya yang tidak sesuai serta kurang transparan dalam menjalankan operasional perusahaan sehingga perencanaan pajak berdampak negatif terhadap nilai perusahaan (Yuliem, 2018). Teori keagenan ini menggambarkan sikap bahwa manajer sebagai agen lebih mementingkan diri sendiri dibandingkan kepentingan para pemegang saham sebagai prinsipal. Hal ini dapat menimbulkan konflik keagenan sehingga diperlukan pihak ketiga yaitu auditor independen untuk mengevaluasi pertanggungjawaban keuangan manajemen, dan memberikan pendapat mengenai kewajaran laporan keuangan yang disajikan oleh manajemen (Hastutik, 2016).

\section{Pengungkapan Human Resources Accounting (HRA) dan Nilai Perusahaan}

Pengungkapan human resources accounting (HRA) merupakan faktor yang sangat penting bagi para pengambil keputusan di era ekonomi berbasis pengetahuan. Akibatnya, setiap organisasi melakukan upaya serius untuk mengungkapkan informasi HRA-nya kepada orang dalam dan orang luar pembuat keputusan. Perusahaan yang lebih besar dengan nilai pasar yang lebih tinggi mengungkapkan lebih banyak informasi HRA daripada perusahaan yang lebih kecil serta perusahaan keuangan mengungkapkan informasi HRA daripada perusahaan non keuangan (Mamun, 2009). Jika perusahaan memiliki sumber daya yang bernilai dan menciptakan nilai, mereka akan mengizinkan stakeholder mengetahui hal ini dengan mengungkapkan informasi. Memaksimalkan nilai perusahaan sangat penting artinya bagi suatu perusahaan, karena dengan memaksimalkan nilai perusahaan berarti juga memaksimalkan tujuan utama perusahaan. Nilai perusahaan yang tinggi akan membuat pasar lebih percaya pada prospek perusahaan dimasa yang akan datang (Pradnyana \& Noviari, 2017). Menurut Anam et al. (2011) jika perusahaan meningkatkan 
tingkat pengungkapan maka akan menghasilkan penurunan kesalahan penilaian dari harga saham dengan demikian akan meningkatkan kapitalisasi pasar perusahaan. Belum terdapat banyak penelitian terkait pengungkapan HRA terhadap nilai perusahaan secara langsung. Namun penelitian Shreelatha et al. (2018) dan penelitian Dhanabhakyam \& Mufliha (2016) menunjukan pengaruh pengungkapan HRA terhadap pengambilan keputusan berinvestasi yang berdampak terhadap nilai perusahaan. Dalam penelitian Shreelatha et al. (2018) menunjukkan bahwa pengungkapan HRA dalam laporan keuangan memiliki dampak tambahan pada proses pengambilan keputusan individu untuk investasi saham. Informasi HRA dapat memainkan peran penting dalam pengambilan keputusan manajerial internal dan langkah-langkahnya dapat digunakan untuk menunjukkan bahwa investasi dalam sumber daya manusia perusahaan dapat menghasilkan keuntungan jangka panjang bagi perusahaan. Penelitian Dhanabhakyam \& Mufliha (2016) menunjukkan bahwa semua aspek yang terkait dengan penerapan akuntansi sumber daya manusia terkait erat dan memiliki 67,1 persen yang berdampak pada bidang pengambilan keputusan praktik manajemen sumber daya manusia. Dengan dilakukannya pengungkapan HRA dapat membantu para investor dalam pengambilan keputusan yang akhirnya akan berdampak pada nilai perusahaan sehingga dapat mencerminkan kemakmuran para pemegang saham. Berdasarkan uraian diatas maka hipotesis pertama yang diajukan dalam penelitian ini adalah pengungkapan human resources accounting berpengaruh signifikan terhadap nilai perusahaan.

\section{Tax Planning dan Nilai Perusahaan}

Perencanaan pajak (tax planning) adalah proses mengorganisasi usaha wajib pajak baik pribadi maupun badan usaha sedemikian rupa dengan memanfaatkan berbagai celah kemungkinan yang dapat ditempuh oleh perusahaan dalam koridor ketentuan peraturan perpajakan (loophole), agar perusahaan dapat membayar pajak dalam jumlah minimum (Pohan, 2013). Disatu sisi, perusahaan yang melaksanakan perencanaan pajak bisa meningkatkan nilai perusahaan. Karena dengan melaksanakan perencanaan pajak, perusahaan bisa lebih efektif dalam membayarkan pajak terutangnya serta terlihat tertib dalam kewajiban perpajakannya (Pradnyana \& Noviari, 2017). Penelitian Herawati \& Ekawati (2016) menyatakan dalam bahwa secara keseluruhan perencanaan pajak berpengaruh terhadap nilai perusahaan. Penelitian ini menggunakan perhitungan cash Effective tax rate, long run cash effective tax rate, book tax difference dan aktifitas tax sheltering untuk variabel perencanaan pajak. Sedangkan untuk nilai perusahaan menggunakan price earnings ratio. Khaoula \& Moez (2019) menunjukkan bahwa ada hubungan positif antara perencanaan pajak dan nilai perusahaan. Selain itu, ditemukan bahwa dewan independensi, keragaman dewan, dan fungsi ganda CEO memiliki pengaruh yang signifikan dan negatif pada hubungan antara perencanaan pajak dan nilai perusahaan. Safitri (2019) juga menyatakan dalam penelitiannya bahwa perencanaan pajak yang diukur dengan menggunakan ETR berpengaruh positif signifikan terhadap nilai perusahaan yang diukur dengan menggunakan EPS pada perusahaan agriculture yang terdaftar di BEI periode 2013-2017 yang mana apabila beban pajak naik maka akan diikuti dengan kenaikan ETR. Pendapat berbeda dikemukakan oleh penelitian Sihotang \& Sitorus (2018) yang menyatakan bahwa tax planning yang diproksikan dengan effective tax rate secara empiris terbukti berpengaruh negatif dan tidak signifikan terhadap firm value. Semakin efektif perusahaan membayar pajaknya ternyata dapat menurunkan nilai perusahaan, tetapi dampak yang diberikan tidak signifikan terhadap nilai perusahaan. Ada kemungkinan hal ini disebabkan pasar kurang berminat pada perusahaan yang kurang efektif dalam perencanaan pajak. Bagi perusahaan, pajak merupakan beban yang menjadi pengurang laba. Hal ini yang menjadi alasan perusahaan melakukan perencanaan pajak agar laba setelah pajak menjadi besar dan akhirnya berpengaruh terhadap nilai perusahaan. Dari uraian tersebut, maka ditetapkan hipotesis kedua dalam penelitian ini yaitu tax planning berpengaruh signifikan terhadap nilai perusahaan.

\section{Kualitas Audit dan Nilai Perusahaan}

Kualitas audit adalah ukuran yang menunjukkan adanya tingkat kompetensi dan indepedensi dari KAP dalam mengaudit laporan keuangan yang diperiksanya sehingga dapat memberikan sutau keyakinan atas pendapat yang telah dikeluarkan dan dapat memberikan suatu jaminan atas reliabilitas dan kualitas dari angkaangka akuntansi dalam laporan keuangan (Juliardi, 2013). Menurut penelitian Bachtiar \& Laksito (2016) dengan judul "Pengaruh Good Corporate Governance, Kualitas Audit dan Profitabilitas terhadap Nilai Perusahaan" menunjukan bahwa secara berasama-sama (Uji F) semua variabel independen mempengaruhi nilai perusahaan. 
Kemudian dalam Uji T hanya variabel profitabilitas saja yang mempengaruhi nilai perusahaan secara signifikan. Sedangkan variabel good corporate governance dan kualitas audit tidak berpengaruh terhadap nilai perusahaan. Nugrahani (2014) menyatakan dalam penelitiannya bahwa variabel kualitas audit tidak memiliki pengaruh signifikan terhadap manajemen laba secara individual. Sedangkan pengaruh manajemen laba terhadap nilai perusahaan, diterima karena terbukti variabel Discretionnary Accruals berpengaruh positif signifikan terhadap nilai perusahaan. Para pemegang saham akan mengambil keputusan berdasarkan laporan keuangan yang telah diaudit oleh seorang auditor. Hasil audit yang baik akan mencerminkan nilai perusahaan yang baik. Walaupun kualitas audit belum tentu mempengaruhi nilai perusahaan secara signifikan. Dari uraian diatas maka ditetapkan hipotesis ketiga yaitu kualitas audit berpengaruh signifikan terhadap nilai perusahaan.

\section{Moderasi Kualitas Audit Atas Pengaruh Pengungkapan HRA Terhadap Nilai Perusahaan}

Auditing merupakan akumulasi dan melakukan evaluasi bukti tentang informasi yang dapat diukur dari suatu entitas ekonomi untuk menentukan dan melaporkan tingkat hubungan informasi dengan kriteria yang telah ditetapkan sebelumnya. Auditing harus dikerjakan oleh seorang independen yang berkompeten (Tandiontong, 2015). Laporan keuangan auditan yang berkualitas yang dilakukan oleh auditor yang berkualitas akan lebih disukai oleh investor, sehingga pasar akan bereaksi positif jika laporan keuangan diaudit oleh auditor yang berkualitas (Nugrahani, 2014). DeAngelo (1981) mendefinisikan kualitas audit sebagai kemampuan auditor untuk menemukan kesalahan atau kecurangan dalam sistem akuntansi dan tekanan dari klien untuk menutup buku secara selektif walaupun kecurangan telah ditemukan. Kode Etik Akuntan tahun 1994 menyebutkan bahwa independensi adalah sikap yang diharapkan dari seorang akuntan publik untuk tidak mempunyai kepentingan pribadi dalam pelaksanaan tugasnya, yang bertentangan dengan prinsip integritas dan obyektivitas. Juliardi (2013) menyatakan bahwa kualitas audit tidak berpengaruh signifikan terhadap nilai perusahaan pada perusahaan manufaktur yang diaudit KAP 4 besar maupun KAP non besar. Ini diartikan bahwa semakin meningkat kualitas audit maka tidak mempengaruhi nilai pasar saham perusahaan-perusahaan manufaktur. Sumber Daya
Manusia adalah aset penting dari suatu organisasi. Namun, tidak ada peraturan hukum untuk akuntansi sumber daya manusia dalam laporan tahunan organisasi mana pun. Implementasi HRA membantu meningkatkan keputusan manajerial seperti PHK, langkah-langkah evaluasi kinerja yang lebih baik dari perusahaan dan juga bertindak sebagai panduan selama transaksi pembelian, penjualan dan merger (Jacob \& Farouq, 2013). Menurut Johanson et al. (1999) dalam penelitiannya menyebutkan bahwa pengambilan keputusan dan pembelajaran investor dan manajer tampaknya dipengaruhi oleh HRCA (Human Resources Costing and Accounting), di mana sebagian besar manajer umumnya memiliki sikap positif terhadap HRCA. Ketika memulai untuk mengimplementasikan HRCA, upaya harus fokus pada (1) pengetahuan tentang biaya, nilai, dan hasil sumber daya manusia serta cara menghitungnya; (2) tuntutan manajemen puncak, serta faktor-faktor lain dalam sistem penghargaan; (3) penetapan target HRCA. Hal ini diperlukan untuk mengimplementasikan HRCA dari perspektif manajemen strategis. Kualitas audit belum tentu mempengaruhi nilai perusahaan secara signifikan. Namun, tindakan kualitas audit diharapkan mampu memoderasi pengaruh dari pengungkapan HRA terhadap nilai perusahan. Maka ditetapkan hipotesis keempat dalam penelitian ini yaitu kualitas audit mampu memoderasi pengaruh pengungkapan HRA terhadap nilai perusahaan.

\section{Moderasi Kualitas Audit Atas Pengaruh tax planning Terhadap Nilai Perusahaan.}

Auditing merupakan akumulasi dan melakukan evaluasi bukti tentang informasi yang dapat diukur dari suatu entitas ekonomi untuk menentukan dan melaporkan tingkat hubungan informasi dengan kriteria yang telah ditetapkan sebelumnya. Auditing harus dikerjakan oleh seorang independen yang berkompeten (Tandiontong, 2015). Laporan keuangan auditan yang berkualitas yang dilakukan oleh auditor yang berkualitas akan lebih disukai oleh investor, sehingga pasar akan bereaksi positif jika laporan keuangan diaudit oleh auditor yang berkualitas (Nugrahani, 2014). DeAngelo (1981) mendefinisikan kualitas audit sebagai kemampuan auditor untuk menemukan kesalahan atau kecurangan dalam sistem akuntansi dan tekanan dari klien untuk menutup buku secara selektif walaupun kecurangan telah ditemukan. Kode Etik Akuntan tahun 1994 menyebutkan bahwa independensi adalah sikap yang diharapkan dari seorang akuntan publik untuk tidak mempunyai 
kepentingan pribadi dalam pelaksanaan tugasnya, yang bertentangan dengan prinsip integritas dan obyektivitas. Juliardi (2013) menyatakan bahwa kualitas audit tidak berpengaruh signifikan terhadap nilai perusahaan pada perusahaan manufaktur yang diaudit KAP 4 besar maupun KAP non besar. Ini diartikan bahwa semakin meningkat kualitas audit maka tidak mempengaruhi nilai pasar saham perusahaan-perusahaan manufaktur. Tujuan dari perencanaan pajak adalah merekayasa agar beban pajak (tax burden) dapat ditekan serendah mungkin dengan memanfaatkan peraturan yang ada untuk memaksimalkan penghasilan setelah pajak (after tax return), karena pajak merupakan unsur pengurang laba yang tersedia, baik untuk dibagikan kepada pemegang saham maupun untuk diinvestasikan kembali. Ketika perusahaan mampu meminimalkan pengeluaran untuk keperluan perpajakan, berarti semakin sedikit beban yang dikeluarkan oleh perusahaan. Semakin kecil beban yang dikeluarkan perusahaan maka semakin besar laba yang diperoleh oleh perusahaan. Minat investor akan semakin tinggi pada saham perusahaan yang memperoleh laba besar. Semakin tinggi minat investor akan suatu saham maka harga saham akan mengalami kenaikan karena jumlah saham yang beredar di masyarakat terbatas (Safitri, 2019). Dalam penelitian Marsaid \& Pesudo (2019) menunjukkan bahwa cash effective tax rates memiliki pengaruh positif dan signifikan terhadap nilai perusahaan. Hal tersebut dikarenakan jumlah kas yang dibayarkan perusahaan untuk membayar kewajiban perpajakannya lebih rendah dengan pajak penghasilan badan yang berlaku sehingga perencanaan pajak yang dilakukan oleh manajemen dapat memberikan kesejahteraan kepada pemegang saham. Ftouhi et al. ( 2015) menyimpulkan bahwa perencanaan pajak mempengaruhi nilai perusahaan secara negatif karena biaya agensi yang lebih tinggi. Hasil penelitian menyatakan bahwa tax Planning tidak berpengaruh terhadap firm value. Hal ini berarti bahwa tinggi rendahnya nilai perusahaan tidak berpengaruh pada tinggi rendahnya nilai perusahaan. Berdasarkan penjelasan diatas, tax planning berpengaruh secara signifikan positif dan negatif terhadap nilai perusahaan. Tindakan kualitas audit diharapkan mampu memoderasi pengaruh dari tax planning terhadap nilai perusahan. Maka ditetapkan hipotesis kelima dalam penelitian inii kualitas audit mampu memoderasi pengaruh tax planning terhadap nilai perusahaan.

\section{METODE PENELITIAN}

Populasi dari penelitian ini adalah seluruh perusahaan manufaktur yang terdaftar di Bursa Efek Indonesia (BEI) selama periode 2014 - 2018. Teknik pengambilan sampel yang digunakan dalam penelitian ini adalah purposive sampling method. Metode ini melakukan pemilihan sampel dengan berbagai pertimbangan/kriteria untuk tujuan tertentu. Adapun kriteria-kretia dalam pemilihan sampel adalah sebagai berikut :

1. Perusahaan manufaktur yang sudah terdaftar di BEI sejak tahun 2014 - 2018 dan selama kurun waktu tersebut tidak pernah keluar dari BEI.

2. Perusahaan manufaktur yang terdiri dari sektor industri barang konsumsi, sektor aneka industri, serta sektor industri dasar dan kimia.

3. Data-data yang dibutuhkan tersedia dalam laporan keuangan.

4. Laporan keuangan tersedia secara berturut-turut selama periode 2014-2018.

5. Perusahaan tidak pernah mengalami kerugian selama periode 2014-2018.

6. Mata uang yang digunakan dalam laporan keuangan adalah rupiah.

\section{Prosedur Pengumpulan Data}

Sumber data dalam penelitian ini adalah data sekunder. Proses pengumpulan data sekunder pada penelitian ini ialah menggunakan pengumpulan data dokumentasi dan studi pustaka pada situs Bursa Efek Indonesia (www.idx.co.id) dan masingmasing website pada perusahaan manufaktur yang bersangkutan berupa laporan keuangan tahunan.

\section{Definisi Operasional dan Pengukuran variabel}

1. Variabel Independen

Variabel independen atau variabel bebas adalah variabel yang mempengaruhi variabel dependen. Variabel independen dalam penelitian ini adalah pengungkapan HRA dan tax planning.

Pengungkapan Human Resources Accounting (HRA)

Akuntansi sumber daya manusia atau Human Resources Accounting (HRA) menyediakan data moneter mengenai sumber daya manusia organisasi yang dianggap penting tidak hanya bagi manajemen dalam mengambil berbagai keputusan tetapi juga untuk analis dan karyawan. Untuk analis itu tidak hanya memberikan informasi mengenai kekuatan dalam organisasi tetapi juga membantu dalam membuat keputusan mengenai investasi jangka panjang dalam organisasi dan ini juga 
mempengaruhi daya tawar dan kinerja karyawan (Dhanabhakyam \& Mufliha, 2016). Indikator pengukuran untuk variabel pengungkapan Human Resources Accounting (HRA) pada penelitian ini menggunakan Human Resource Accounting Disclosure Index (HRADI) menurut Al Mamun (2009) yang terdiri dari enam belas (16) item pengungkapan, sebagai berikut: (1)Separete HRA statements, (2)Total Value of Human resource, (3)Number of employess, (4) Human resource policy, (5) Training and developmet, (6) Management succession plan, (7) Employement report, (8) Employess' value addition, (9) Human resource development fund, (10) Employees/workers fund, (11) Employee categories, (12) Managerial remuneration, (13) Retirement benefits (14) Performance recognition, (15) Super annuation fund, (16) Other employees benefits. Item pengungkapan HRA diperiksa dengan prosedur pemberian skor "1" jika perusahaan telah melakukan pengungkapan, dan " 0 " jika sebaliknya. HRADI dapat diformulasikan sebagai berikut:

$H R A D I=\frac{\text { Total Score of Individual Company }}{\text { Maximum Possible Score Obtainable }} \times 100 \%$ Tax Planning

Perencanaan Pajak (Tax Planning) adalah langkah awal dalam manajemen pajak dimana pada tahap ini dilakukan pengumpulan dan penelitian terhadap peraturan perpajakan, dengan maksud dapat diseleksi jenis tindakan penghematan pajak yang akan dilakukan. Variabel perencanaan pajak dalam penelitian ini diukur menggunakan Tarif Pajak Efektif atau Effective Tax Rate (ETR) seperti yang dilakukan oleh penelitian Safitri (2019), semakin kecil nilai ETR berarti perencanaan untuk penghindaran pajak oleh perusahaan semakin besar dan begitu pula sebaliknya semakin besar nilai ETR maka perencanaan untuk penghindaran pajaknya semakin kecil. Nilai ETR berkisar lebih dari 0 dan kurang dari 1, dengan rumus sebagai berikut :

$$
\text { ETR }=\frac{\text { Beban Pajak Penghasilan }}{\text { Pendapatan sebelum pajak }}
$$

2. Variabel Dependen

Variabel dependen atau variabel terikat adalah variabel yang dipengaruhi oleh variabel lain (variabel independen). Variabel dependen dalam penelitian ini adalah nilai perusahaan. Nilai perusahaan dapat memberikan kemakmuran kepada pemegang saham secara maksimum apabila harga saham meningkat. Semakin tinggi harga saham, maka semakin tinggi tingkat kemakmuran dari pemegang saham (Mahpudin \& Suparno, 2016). Nilai perusahaan dalam penelitian ini diukur menggunakan Price Earning Ratio (PER) seperti yang dilakukan oleh Syahidatul Marfuah et al. (2019), yang diformulasikan:

et al. (2019), yang diformulasikan:

\section{Variabel Moderating}

Variabel moderating adalah variabel yang memperkuat atau memperlemah hubungan anatara variabel dependen dengan variabel independen. Variabel moderating dalam penelitian ini adalah kualitas Audit. DeAngelo (1981) mendefinisikan kualitas audit sebagai kemampuan auditor untuk menemukan kesalahan atau kecurangan dalam sistem akuntansi dan tekanan dari klien untuk menutup buku secara selektif walaupun kecurangan telah ditemukan. Variabel ini menggunakan proksi jumlah auditor yang digunakan oleh DeAngelo (1981), semakin banyak jumlah tenaga kerja profesional dalam melakukan pemerikasaan laporan keuangan maka semakin baik kualitas auditnya. Rumus dari perhitungan ini adalah:

\section{Kualitas Audit = Jumlah Auditor}

\section{Model Penelitian}

Model penelitian dalam penelitian ini dapat digambarkan sebagai berikut:

Gambar 3.1

Model Penelitian

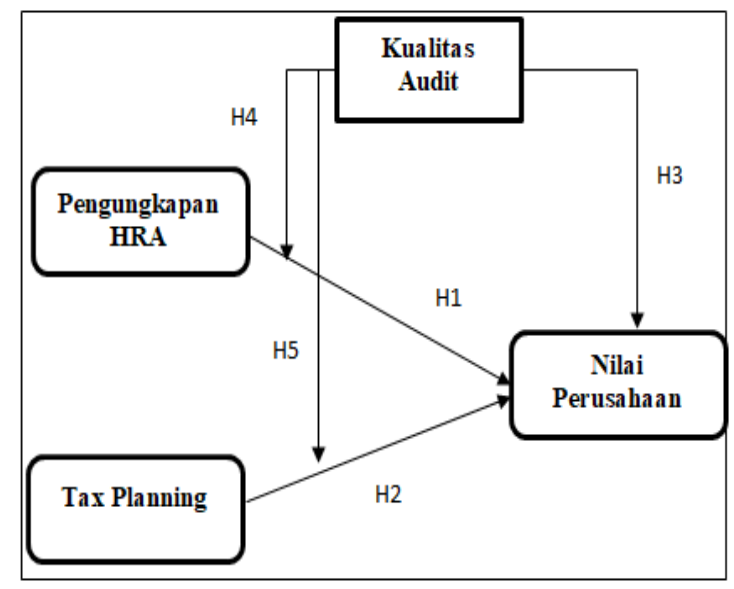

\section{Jenis Penelitian}

Jenis penelitian ini adalah penelitian kuantitatif. Hal ini ditunjukan dengan adanya hubungan antar variable dan bertujuan untuk menguji hipotesis atau teori yang telah ada. Berdasarkan tingkat eksplanasinya penelitian ini 
termasuk penelitian korelasional karena bertujuan untuk menemukan apakah terdapat hubungan antara dua variabel atau lebih, serta seberapa besar korelasi yang ada diantara variabel yang diteliti.

\section{Teknik Analisis}

\section{Regresi Linear Berganda}

Teknik analisis yang digunakan dalam penelitian ini adalah model regresi linear berganda. Model regresi linear berganda bertujuan untuk mengetahui pengaruh ataupun juga hubungan antara dua variabel independen atau lebih terhadap satu variabel dependen. Pengolahan data penelitian dibantu dengan menggunakan STATA. Persamaan regresi berganda yang diinterpretasikan dalam penelitian ini adalah:

$$
\mathrm{Y}=\alpha+\beta_{1} \mathrm{HRA}+\beta_{2} \mathrm{ETR}+\beta_{3} \mathrm{KA}+e
$$

\section{Keterangan :}

Y : Nilai perusahaan diukur dengan proksi PER

$\alpha \quad$ : Konstanta

$\beta \quad$ : Koefisien variabel

HRADI : HRA diproksikan dengan HRADI (Human Resources Accounting Disclosure Indeks)

ETR : Tax Planning diproksikan dengan ETR

KA : Kualitas Audit diproksikan dengan jumlah auditor

$e \quad:$ Error (Kesalahan Pengganggu)

\section{Pengujian Kelayakan Data}

1. Uji Normalitas

Uji normalitas dilakukan untuk mengetahui normal atau tidaknya suatu distribusi data. Untuk mengetahui normal atau tidaknya suatu data dapat dilihat dari asumsi kolgomorovsmirnov pada nilai sig. Apabila nilainya signifikan maka data distribusi normal.

2. Uji Multikolinieritas

Uji ini dilakukan pada penelitian yang memiliki variabel independen lebih dari satu. keputusan yang di ambil ada tidaknya multikolinearitas adalah jika nilai VIF > 10 dapat di indikasikan terjadi multikolinearitas dan jika nilai VIF $<10$ dapat di indikasikan tidak terjadi multikolinearitas.

3. Uji Autokorelasi

Uji autokorelasi bertujuan untuk menguji apakah dalam model regresi linier ada korelasi antara kesalahan pengganggu pada periode $t$ dengan kesalahan pengganggu periode $\mathrm{t}-1$.
Dengan cara membandingkan nilai Durbin Waston dan Durbin Waston tabel.

\section{Uji Hipotesis}

1. Uji $\mathrm{F}$

Uji F merupakan salah satu alat analisis uji hipotesis yang digunakan untuk menunjukan seberapa jauh atau adakah hubungan antara variabel independen secara keseluruhan dan bersama-sama mempengaruhi variabel dependen (Nurjanah et al., 2019). Kriteria Penilaian uji $\mathrm{F}$ adalah apabila Sig. F $<0,05$ maka H1 menunjukkan bahwa ada beberapa variabel bebas yang memiliki kemampuan untuk menjelaskan variasi variabel terikat. Apabila Sig. F > 0,05 maka H0 menunjukkan bahwa variabel bebas tidak mampu menjelaskan variasi variabel terikat.

\section{Koefisien Determinasi (R2)}

Koefisien determinasi dimasukkan untuk mengetahui tingkat ketepatan paling baik dalam analisis regresi.Selain itu koefisien determinasi di pergunakan untuk mengetahui presentase perubahan variabel terikat yang disebabkan oleh variabel bebas (Nurjanah et al., 2019).

\section{HASIL PENELITIAN DAN PEMBAHASAN}

Penelitian ini dilakukan dengan sampel sebanyak 45 perusahaan dalam sektor manufaktur yang terdaftar di Bursa Efek Indonesia (BEI) dengan jangka waktu lima (5) tahun yaitu 20142018. Adapun hasil analisis dari penilitian ini ialah sebagai berikut:

\section{Statistik Deskriptif}

Hasil uji deskriptif variabel dapat dilihat pada tabel berikut ini:

Tabel 4.1

Statistik Deskriptif

\begin{tabular}{|r|rrrrr|}
\hline Variable & Obs & Mean & Std. Dev. & Min & Max \\
\hline y & 225 & 23.60494 & 51.37079 & .3018373 & 500 \\
81 & 225 & .4975 & .1117909 & .1875 & .75 \\
82 & 225 & .2384953 & .0866936 & .01 & .580871 \\
$z$ & 225 & 459.2578 & 227.5083 & 19 & 840 \\
\hline
\end{tabular}

Keterangan:

$\mathrm{Y}=$ Nilai Perusahaan, $\mathrm{X} 1=$ Pengungkapan HRA,

X2 = Tax Planning, $Z=$ Kualitas Audit

Sumber: Output Stata, 2020 
Tabel diatas menggambarkan hasil deskripsi variabel-variabel secara statistik dalam penelitian ini. Minimum merupakan nilai terkecil dari suatu rangkaian pengamatan, maksimum merupakan nilai terbesar dari suatu rangkaian pengamatan, mean (rata-rata) adalah hasil penjumlahan nilai seluruh data dibagi dengan banyaknya data, sementara standar deviasi adalah akar dari jumlah kuadrat dari selisih nilai data dengan rata-rata dibagi dengan banyaknya data. Tabel 4 menunjukkan statistik deskriptif variabel penelitian dengan jumlah data setiap variabel yang valid sebanyak 225 adalah sebagai berikut: Nilai perusahaan (Y) memiliki nilai minimum sebesar 0,3018373 dan nilai maksimum sebesar 500. rata-rata nilai perusahaan adalah 23,60494 dengan standar deviasi sebesar 51,370379. Pengungkapan HRA (X1) memiliki nilai minimum 0,1875 dan nilai maksimum sebesar 0,75 . Nilai rata-rata pengungkapan HRA adalah 0,4975 dengan standar deviasi sebesar 0,1117909. Tax planning (X2) memiliki nilai minimum 0,01 dan nilai maksimum sebesar 0,580871 . Nilai ratarata tax planning adalah 0,2384953 dengan standar deviasi sebesar 0,8066936. Kualitas audit (Z) memiliki nilai minimum 19 dan nilai maksimum 840. Nilai rata-rata kulaitas audit adalah 459,2578 dengan standar deviasi 227,5083.

\section{Uji Kelayakan Data}

Hasil uji kelayakan data menggunakan uji normalitas, uji multikolinieritas, dan uji auto korelasi. Data terdistribusi normal karena nilai kolgomorov-smirnov menunjukkan nilai yang signifikan. Tidak terdapat masalah multikolinieritas karena nilai variasi inflasi faktor tidak lebih dari 10 dan nilai tollerance diatas 0,1 . Hasil uji durbin watson menunjukkan bahwa hasilnya berada diantara -2 sampai 2.

\section{Hasil Uji Hipotesis}

Pengaruh pengungkapan HRA, tax planning, dan kualitas audit terhadap nilai perusahaan dengan menggunakan tingkat signifikansi lima persen $(5 \%)$ diuji dengan menggunakan model regresi linear berganda.
Tabel 4.2

Interpretasi Regresi Variabel Independen Terhadap Variabel Dependen

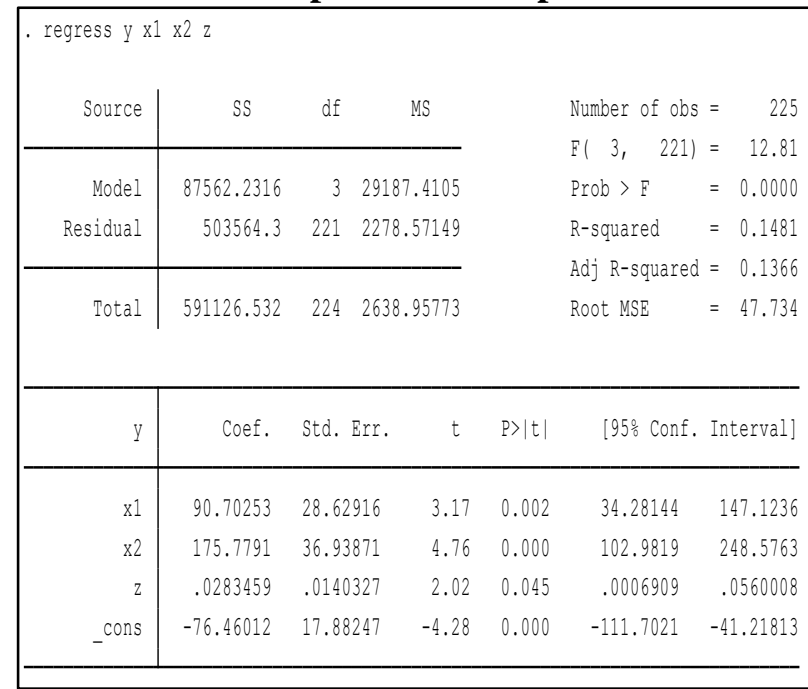

Keterangan:

$\mathrm{Y}=$ Nilai Perusahaan, $\mathrm{X} 1=$ Pengungkapan HRA,

$\mathrm{X} 2$ = Tax Planning, $\mathrm{Z}=$ Kualitas Audit

Sumber: Output Stata, 2020

Dari uji Anova atau Uji F diatas,

nilai $F$ hitung 12,81 dengan probabilitas signifikansi yang menunjukkan 0,000 . Nilai probabilitas pengujian yang lebih kecil dari $\alpha=$ 0,05 . Hal ini menunjukkan bahwa secara bersamasama (simultan) nilai perusahaan dipengaruhi oleh pengungkapan human resources accounting, tax planning dan kualitas audit. Berdasarkan data di atas, maka dapat disimpulkan persamaan regresi berganda dalam penelitian ini ialah:

\section{$\mathrm{Y}=-\mathbf{7 6 , 4 6 0}+$ 90,703 HRA + 175,991 ETR + $0,028 \mathrm{KA}+e$}

Berdasarkan persamaan regresi linear berganda di atas dapat dijelaskan bahwa: Koefisien konstanta adalah sebesar -76,460, artinya bila ketiga variabel pengungkapan HRA (HRA), tax planning (ETR) dan kualitas audit (KA) konstan atau perubahannya sama dengan nol maka nilai perusahaan (Y) adalah sebesar -76,460. Nilai koefisien regresi pengungkapan HRA $(\mathrm{HRA})=$ 90,703 secara statistik menunjukkan bahwa ada pengaruh positif variabel pengungkapan HRA pada nilai perusahaan. Nilai koefisien sebesar 90,703 memiliki arti jika nilai pengungkapan HRA meningkat sebesar 1 satuan, maka nilai perusahaan meningkat sebesar 90,703 dengan asumsi variabel lain konstan. Nilai koefisien regresi tax planning $(\mathrm{ETR})=175,991$ secara statistik menunjukkan bahwa ada pengaruh positif variabel tax planning terhadap nilai perusahaan. Nilai koefisien sebesar 175,991 memiliki arti jika nilai tax planning meningkat sebesar 1 satuan, maka nilai perusahaan 
meningkat sebesar 175,991 dengan asumsi variabel lain konstan. Nilai koefisien regresi kualitas audit $(\mathrm{KA})=0,028$ secara statistik menunjukkan bahwa ada pengaruh positif variabel kualitas audit terhadap nilai perusahaan. Nilai koefisien sebesar 0,028 memiliki arti jika nilai kinerja keuangan naik sebesar 1 satuan, maka nilai perusahaan meningkat sebesar 0,028 dengan asumsi variabel lain konstan. $R$-Squared adalah Koefisien Determinasi Berganda, artinya seberapa besar secara simultan semua variabel independen dapat menjelaskan variabel dependen. Di atas nilainya 0,1481 yang berarti semua variabel independen dapat menjelaskan variabel dependen sebesar $14,81 \%$. Maka sisanya yaitu $100 \%-14,81 \%=85,19 \%$ dipengaruhi oleh variabel lain diluar model regresi.

Tabel 4.3

Interpretasi Varibel Moderating

\begin{tabular}{|c|c|c|c|c|c|c|}
\hline \multicolumn{7}{|c|}{ regress y $x 1 z \times 2 z$} \\
\hline Source & SS & df & MS & \multirow{4}{*}{\multicolumn{3}{|c|}{ 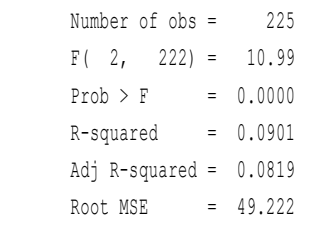 }} \\
\hline Model & 53252.96 & 2 & 26626.48 & & & \\
\hline Residual & 537873.572 & 2222 & 2422.85393 & & & \\
\hline Total & 591126.532 & 2242 & 2638.95773 & & & \\
\hline y & Coef. & Std. En & rr. & $P>|t|$ & [95\% Conf. I & Interval] \\
\hline $\mathrm{x} 12$ & -.0084964 & .036770 & -0.23 & 0.817 & -.0809607 & .0639679 \\
\hline$\times 22$ & .223705 & .063773 & 3.51 & 0.001 & .0980269 & .3493832 \\
\hline cons & 1.216719 & 6.91291 & 0.18 & 0.860 & -12.40662 & 14.84006 \\
\hline
\end{tabular}

Keterangan:

$\mathrm{Y}=$ Nilai Perusahaan, $\mathrm{X} 1=$ Pengungkapan HRA,

X2 = Tax Planning, $Z=$ Kualitas Audit

Sumber: Output Stata, 2020

\section{Pengaruh Pengungkapan Human Resources Accounting (HRA) Terhadap Nilai Perusahaan}

Pengujian hipotesis pertama dalam penelitian ini adalah untuk menguji apakah pengungkapan HRA berpengaruh terhadap nilai perusahaan. Hasil dari regresi menunjukkan nilai t hitung sebesar 3,17 dengan probabilitas signifikansi adalah 0,002 berada lebih rendah pada $\alpha=0,05$, sehingga hasil penelitian ini mendukung hipotesis yang diajukan. Hal ini mengindikasikan bahwa pengungkapan human resources accounting berpengaruh positif terhadap nilai perusahaan. Pada tabel 5 pengungkapan human resources accounting (HRA) memberikan nilai koefisien parameter dengan koefisien 90,70251 dan probabilitas signifikansi 0,002. Hasil ini dapat disimpulkan bahwa semakin tinggi tingkat pengungkapan HRA suatu perusahaan maka dapat meningkatkan nilai perusahaan. Hal ini diakibatkan karena dengan adanya pengungkapan HRA perusahaan maka akan direspon positif oleh investor sehingga banyak investor yang berinvestasi pada perusahaan tersebut yang menyebabkan meningkatnya nilai perusahaan. Akuntansi sumber daya manusia atau Human Resources Accounting (HRA) menyediakan data moneter mengenai sumber daya manusia organisasi yang dianggap penting tidak hanya bagi manajemen dalam mengambil berbagai keputusan tetapi juga untuk analis dan karyawan. Hasil penelitian ini mengkonfirmasi penelitian terdahulu diantaranya, Anam et al. (2011), Dhanabhakyam \& Mufliha (2016), dan Shreelatha et al. (2018) yang menunjukan pengaruh pengungkapan HRA terhadap pengambilan keputusan berinvestasi yang berdampak signifikan terhadap nilai perusahaan.

\section{Pengaruh Tax Planning Terhadap Nilai Perusahaan}

Pengujian hipotesis kedua dalam penelitian ini adalah menguji pengaruh tax planning terhadap nilai perusahaan. Hasil dari regresi menunjukkan nilai $\mathrm{t}$ hitung sebesar 4,76 dengan probabilitas signifikan $0,000<0,05$ artinya hipotesis kedua diterima dan dapat disimpulkan bahwa tax planning berpengaruh positif terhadap nilai perusahaan. Hal ini diakibatkan karena dengan adanya perencanaan pajak yang benar maka akan memberikan laba yang besar bagi perusahaan sehingga nilai perusahaan akan meningkat. Pada tabel 5, variabel tax planning memberikan nilai koefisien parameter sebesar 175,7791 dan probabilitas signifikansi 0,000. Hal ini disebabkan karena investor lebih tertarik dengan perusahaan yang memiliki laba yang besar sehingga berdampak pada kenaikan nilai perusahaan. Namun pihak perusahaan harus berupaya agar perencanaan pajak yang dilakukan tidak melanggar hukum yang berlaku. Perusahaan yang melaksanakan perencanaan pajak bisa meningkatkan nilai perusahaan. Karena dengan melaksanakan perencanaan pajak, perusahaan bisa lebih efektif dalam membayarkan pajak terutangnya serta terlihat tertib dalam kewajiban perpajakannya (Pradnyana \& Noviari, 2017). Hasil penelitian ini didukung oleh penelitian terdahulu diantanya, Safitri (2019) yang juga menyatakan dalam penelitiannya bahwa perencanaan pajak yang diukur dengan menggunakan ETR berpengaruh positif signifikan terhadap nilai perusahaan. Penelitian Khaoula \& Moez (2019) juga menunjukkan bahwa ada hubungan positif antara perencanaan pajak dan nilai perusahaan. Selain itu penelitian Herawati \& Ekawati (2016) juga 
menyatakan bahwa secara keseluruhan perencanaan pajak berpengaruh terhadap nilai perusahaan.

\section{Pengaruh Kualitas Audit Terhadap Nilai Perusahaan}

Pengujian hipotesis ketiga dalam penelitian ini adalah menguji pengaruh kualitas audit terhadap nilai perusahaan. Hasil dari regresi menunjukkan nilai $\mathrm{t}$ hitung sebesar 2,02 dengan probabilitas signifikansi lebih kecil dari 0,05 yaitu 0,045 sehingga hipotesis ketiga diterima artinya kualitas audit berpengaruh positif terhadap nilai perusahaan. Berdasarkan hasil analisis pada tabel 5 ditunjukkan bahwa koefisien parameter kualitas audit sebesar 0,0283459 dengan signifikansi 0,045 yang berarti semakin baik kualitas seorang auditor maka semakin meningkatkan nilai perusahaan. Dalam penelitian ini kualitas audit diukur dengan banyaknya jumlah auditor, hal ini menunjukkan bahwa semakin banyak auditor independen di suatu KAP (kantor akuntan publik) maka kualitas auditnya akan semakin baik dan dapat menghasilkan laporan keuangan yang terpercaya. Para pemegang saham akan mengambil keputusan berdasarkan laporan keuangan yang telah diaudit oleh seorang auditor. Hasil audit yang baik akan mencerminkan nilai perusahaan yang baik. Hasil penelitian ini tidak endukung hasil penelitian terdahulu seperti Bachtiar \& Laksito (2016) dan Nugrahani (2014) yang menyatakan dalam penelitiannya bahwa variabel kualitas audit tidak memiliki pengaruh signifikan terhadap nilai perusahaan. Selain itu Juliardi (2013) menyatakan bahwa kualitas audit tidak berpengaruh signifikan terhadap nilai perusahaan pada perusahaan manufaktur yang diaudit KAP 4 besar maupun KAP non besar. Ini diartikan bahwa semakin meningkat kualitas audit maka tidak mempengaruhi nilai pasar saham perusahaan-perusahaan manufaktur.

\section{Moderasi Kualitas Audit Atas Pengaruh Pengungkapan HRA Terhadap Nilai Perusahaan}

Berdasarkan data pada tabel 6 pengujian regresi moderasi kualitas audit atas pengungkapan human resources accounting (HRA) terhadap nilai perusahaan menunjukkan bahwa variabel interaksi pengungkapan HRA dengan kualitas audit (X1Z) memiliki tingkat probabilitas 0,817 atau lebih besar dari 0,05 dan nilai koefisien yang dihasilkan negatif yaitu -0,0084964. Secara empiris moderasi pengungkapan HRA tidak mampu memperkuat pengaruh pengungkapan HRA terhadap nilai perusahaan. Meskipun arah pengaruh yang dihasilkan berubah menjadi positif tetapi tetap tidak signifikan. Adanya kemungkinan publik menganggap bahwa pengungkapan HRA tidak begitu penting dan publik juga menganggap masih adanya sikap tidak independen seorang auditor dalam melakukan pemeriksaan laporan keuangan. Sehingga kualitas audit yang bertujuan membantu investor dalam pengambilan keputusan tidak mampu memperkuat pengaruh dari pengungkapan HRA.

\section{Moderasi Kualitas Audit Atas Pengaruh Tax Planning Terhadap Nilai Perusahaan}

Berdasarkan data pada tabel 6 pengujian regresi moderasi kualitas laba atas tax planning terhadap nilai perusahaan menunjukkan bahwa variabel interaksi tax planing dengan kualitas audit (X2Z) memiliki tingkat probabilitas 0,001 atau lebih kecil dari 0,05 dan nilai koefisien yang dihasilkan positif yaitu 0,223705. Hal ini menunjukkan bahwa secara empiris moderasi kualitas laba mampu memoderasi pengaruh tax planning terhadap nilai perusahaan. Minat investor akan semakin tinggi pada saham perusahaan yang memperoleh laba besar. Semakin tinggi minat investor akan suatu saham maka harga saham akan mengalami kenaikan karena jumlah saham yang beredar di masyarakat terbatas (Safitri, 2019). Sebelum berinvestasi para investor menggunakan laporan keuangan sebagai bahan informasi perusahaan dalam pengambilan keputusan sehingga laporan yang disajikan perusahaan harus berkualitas baik dan sudah diaudit oleh seorang auditor independen. Hal ini yang menyebabkan kualitas audit dapat meperkuat pengaruh tax planning terhadap nilai perusahaan. Secara praktis penelitian ini dapat bermanfaat sebagai bahan pertimbangan bagi investor dalam mengambil keputusan dan digunakan sebagai bahan evaluasi perusahaan dalam mengingkatkan nilai perusahaan agar lebih baik lagi kedepannya. Serta dapat digunakan sebagai bahan referensi pada penelitianpenelitian selanjutnya

\section{KESIMPULAN}

Dari penelitian ini dapat disimpulkan bahwa secara empiris pengungkapan human resources accounitng berpengaruh positif dan signifikan terhadap nilai perusahaan. Semakin tinggi pengungkapan HRA yang dilakukan oleh perusahaan, maka dapat meningkatkan nilai perusahaan. Secara empiris tax planning berpengaruh positif dan signifikan terhadap nilai 
perusahaan. Hal ini menunjukkan bahwa perencanaan pajak yang baik dapat meningkatkan laba perusahaan setelah pajak yang berdampak pada peningkatan nilai perusahaan. kualitas audit berpengaruh positif signifikan terhadap nilai perusahaan artinya semakin baik audit yang dilakukan oleh auditor independen akan menghasilkan laporan keuangan yang berkualitas baik dan mempengaruhi investor untuk berinvestasi sehingga nilai perusahaan menjadi tinggi. Kualitas audit tidak mampu memoderasi atas pengaruh pengungkapan HRA terhadap nilai perusahaan. kualitas audit yang dilakukan untuk menghasilkan laporan keuangan yang berkualitas tidak dapat memperkuat pengaruh pengungkapan HRA terhadap nilai perusahaan di pasar. Sedangkan kualitas audit mampu memperkuat memoderasi atas pengaruh tax planning terhadap nilai perusahaan. Perencanaan pajak yang semakin baik akan menghasilkan laba yang besar dan berdampak pada kenaikan nilai perusahaan.

Hasil penelitian ini memiliki beberapa keterbatasan diantaranya belum menggunakan variabel kontrol, sampel yang digunakan dalam penelitian hanya 45 perusahaan dari semua sektor manufaktur, tidak semua perusahaan manufaktur memberikan informasi lengkap mengenai human resource accounting (sumber daya manusia) dan proksi yang digunakan untuk pengungkapan HRA merupakan indeks pengungkapan HRA, sehingga pemahaman peneliti terhadap indeks pengungkapan bisa jadi berbeda dengan yang lain.

\section{Saran}

Saran peneliti bagi pihak perusahaan, berdasarkan hasil penelitian ini dapat dibuktikan bahwa pengungkapan HRA (human resources accounting) mampu meningkatkan nilai perusahaan, sehingga setiap perusahaan diharapkan dapat melaporkan pengungkapan HRA secara lengkap dalam laporan tahunannya. Adanya perencanaan pajak juga mempengaruhi nilai perusahaan, sehingga ketika perusahaan mampu melakukan aktivitas perencanaan pajak tanpa melanggar hukum maka dapat memperoleh laba yang lebih besar. Selain itu perlu juga diperhatikan penggunaan auditor independen yang digunakan perusahaan agar laporan keuangan berkualitas baik dan mampu meningkatkan nilai perusahaan. Bagi penelitian selanjutnya, penulis berharap agar dilakukan penelitian pada sektor usaha selain manufaktur dengan rentang waktu yang lebih panjang dan menggunakan indikator pengukuran yang terbaru untuk setiap variabel penelitian.

\section{DAFTAR PUSTAKA}

Anam, A., Fatima, O., Majdi, A. R. H., \& Abdul. (2011). Effects of intellectual capital information disclosed in annual reports on market capitalization. Journal of Human Resource Costing \& Accounting, 15(2), 85101.

Bachtiar, M. Y., \& Laksito, H. (2016). Pengaruh Good Corporate Governance, Kualitas Audit Dan Profitabilitas Terhadap Nilai Perusahaan (Studi Empiris Pada Perusahaan Yang Terdaftar Di Bursa Efek Indonesia Tahun 2012-2014).

DeAngelo, L. E. (1981). Auditor size and audit quality. Journal of Accounting and Economics, 3(3), 183-199.

Dhanabhakyam, M., \& Mufliha, S. (2016). Impact of human resource accounting system on the decisions making areas of human resource management practices. International Journal of Applied Research, 2(5), 505-508.

Flamholtz, E. G., Bullen, M. L., \& Hua, W. (2002). Human resaources Accounting: A Historical Perspective and Future Implications. Management decision (ABI/INFORM Global),. Management Decision (Vol. 40).

Ftouhi, K., Ayed, A., \& Zemzem, A. (2015). Tax Planning and Firm Value: Evidence from European Companies. International Journal Economics \& Strategic Management of Business Process, 4, 73-78.

Hastutik, R. D. (2016). Pengaruh Masa Perikatan Audit, Rotasi KAP, Ukuran Perusahaan dan Ukuran KAP terhadap Kualitas Audit ( Studi Empiris Pada Perusahaan Manufaktur Kimia yang Terdaftar di Bursa Efek Indonesia (BEI) periode 2011-2014). Skripsi Thesis Universitas Muhammadiyah Surakarta.

Herawati, H., \& Ekawati, D. (2016). Pengaruh Perencanaan Pajak Terhadap Nilai perusahaan. Jurnal Riset Akuntansi Dan Keuangan, 4(1), 873-884.

Jacob, J., \& Farouq, S. (2013). A Review of Human Resource Accounting and Organizational Performance. International Journal of Economics and Finance, 5(8), 74 83.

Jensen, M., \& Meckling, W. (1976). Theory Of The Firm: Managerial Behavior, Agency Costs and Ownership Structure. Journal of Financial Economics, 3(4), 305-360.

Johanson, U., Eklov, G., Holmgren, M., \& Martersson, M. (1999). Human resource costing and accounting versus the BSC. 
Literature survey of experience with the concepts. A Report to OECD.

Juliardi, D. (2013). Pengaruh Leverage, Konsentrasi Kepemilikan, Dan Kualitas Audit Terhadap Nilai Perusahaan Serta Laba Persisten Pada Perusahaan Publik Manufaktur Yang Listed Di Bursa Efek Indonesia. Jurnal Akuntansi Aktual, 2(2), 113-122.

Khaoula, F., \& Moez, D. (2019). The moderating effect of the board of directors on firm value and tax planning: Evidence from European listed firms. Borsa Istanbul Review.

Lestari, N. (2016). Pengaruh Tax Planning Terhadap Nilai Perusahaan. Akuntabilitas, 7(1), 69-83.

Lisa, O. (2012). Asimetri Informasi Simetri Informasi dan Manajemen Laba. Jurnal WIGA, 2(1), 42-49.

Mahpudin, E., \& Suparno. (2016). Faktor Faktor Yang Mempengaruhi Nilai Perusahaan (Studi empiris Pada Perusahaan Manufaktur yang terdaftar di Bursa Efek Indonesia). Jurnal Riset Keuangan Dan Akuntansi, 2(2), 56-75.

Mamun, S. A. (2009). Human resource accounting (HRA) disclosure of Bangladeshicompanies and its association with corporate characteristics. BRAC University Journal, 1(1), 35-43.

Marfuah, S., Nurlaela, S., \& Wijayanti, A. (2019). Beban Pajak, Nilai Perusahaan Dan Exchange Rate Dan Transfer Pricing Pada Perusahaan Pertambangan. Jurnal Ekonomi Paradigma, 21(01), 73-81.

Marsaid, M. T., \& Pesudo, D. A. (2019). Pengaruh Tax Planning Terhadap Nilai Perusahaan. Jurnal Bingkai Ekonomi, 4(2), 11-24.

Nugrahani, C. (2014). Pengaruh Kualitas Audit Terhadap Nilai Perusahaan (Manajemen Laba Sebagai Variabel Intervening). Kiat Bisnis, 5(4).

Nugraheni, B. D. (2018). FAktor-faktor yang Berpengaruh terhdap Luas Pengungkapan Sukarela dalam Laporan Tahunan. EKUITAS (Jurnal Ekonomi Dan Keuangan), 16(3), 352-367.
Nurjanah, I., Susyanti, J., \& Salim, M. A. (2019). Pengaruh Leverage, Profitability, Ukuran Perusahaan Dan Proporsi Kepemilikan Institusional Terhadap Tax Planning. Jurnal Ilmiah Riset Manajemen, 8(4).

Pohan, C. A. (2013). Manajemen Perpajakan: Strategi Perencanaan Pajak dan Bisnis. (Cetakan Pertama). Jakarta: Gramedia Pustaka Utama.

Pradnyana, I. B. G. P., \& Noviari, N. (2017). Pengaruh Perencanaan Pajak Terhadap Nilai Perusahaan dengan Transparasi Perusahaan Sebagai Variabel Moderasi. E-Jurnal Akuntansi, 18(2), 1398-1425.

Safitri, W. (2019). Pengaruh Perencanaan Pajak Terhadap Nilai Perusahaan pada Perusahaan Agriculture yang Terdaftar di BEI.

Shreelatha, Sinha, R., \& Sambargi, S. (2018). Disclosing Human Resource AccountingEffect On Stock Investment Decision. International Journal of Recent Scientific Research, 9(D), 28910-28912.

Sihotang, W., \& Sitorus, R. R. (2018). Pengaruh Struktur Ownership Dan Tax Planning Terhadap Firm Value Dengan Manajemen Laba Sebagai Variabel Pemoderasi. MEDIA AKUNTANSI PERPAJAKAN, 3(1), 1-14.

Tandiontong, M. (2015). Kualitas Audit dan Pengukurannya. Alfabeta, 1-248.

Tjandrakirana, R., \& Monika, M. (2014). Pengaruh Kinerja Keuangan Terhadap Nilai Perusahaan pada Perusahaan Manufkatur yang Terdaftar di Bursa Efek Indonesia. Jurnal Manajemen Dan Bisnis, 12(1), 1-73.

Widodo, N. (2014). Pengaruh Karakteristik Perusahaan terhadap Pengungkapan Akuntansi Sumber Daya Manusia. Simposium Nasional Akuntansi XVII. Lombok, 23-27.

Yuliem, M. (2018). Pengaruh Perencanaan Pajak ( Tax Planning ) Terhadap Nilai Perusahaan ( Firm Value ) Pada Perusahaan Sektor Non Keuangan Yang Terdaftar di BEI Periode 2013-2015, 7(1), 520-540. 